\title{
Metal Complexes Derived from Mixed Azo-linked Schiff-base Ligand with Dithiocarbamate Derivative: Formation, Spectral Characterization and Biological Study
}

\author{
AHMED K. HUSSIEN, ENAAM I. YOUSIF*, HASAN A. HASAN and RIYADH M. AHMED \\ Department of Chemistry, College of Education for Pure Science(Ibn Al-Haitham), \\ University of Baghdad, P.O. Box 4150, Adhamiyah, Baghdad, Iraq. \\ ${ }^{*}$ Corresponding author E-mail: enaamismail@yahoo.com \\ http://dx.doi.org/10.13005/ojc/340340
}

(Received: December 07, 2017; Accepted: June 06, 2018)

\begin{abstract}
The study includes preparation and characterisation of mixed azo-linked Schiff-base and DTCs ligands and their complexes. The starting material was isolated from the mixing of naphthyl amine diazonium salt with 2-aminophenolein a 1:1 mole ratio in water. In this work, the formation of azo-linked Schiff-base and DTCs ligands are reported. Ligand of the azo-linked Schiff-base was achieved by the reaction of starting material with 4-(dimethylamino)benzaldehyde) $\left(\mathrm{HL}^{1}\right)$. The DTCs was isolated by the reaction of $\left(\mathrm{C}_{6} \mathrm{H}_{5}\right)_{2} \mathrm{NH}$ with carbon disulphide in potassium hydroxide $\left(\mathrm{L}^{2}\right)$. The complexes were prepared by mixing the azo-linked Schiff-base ligand and DTCs ligand with the metal salts; Co", $\mathrm{Ni"}$, Zn" and Cd" in a 1:1:1 mole ratio. Ligands and complexes were characterised by analytical and spectroscopic analyses including; microanalysis, chloride content, thermal analysis, magnetic susceptibility for complexes, conductance, FTIR, UV-Vis and ${ }^{1} \mathrm{H}$-NMR spectroscopy. Physico-chemical techniques indicated complexes demonstrated four and six coordinate structures in the solid and solution state. Biological activity of the ligands and their metal complexes were screened for their antimicrobial activity against four bacterial species (Escherichia coli and Enterobacter Gram - ve, (Bacillus stubtilis and Staphylococcus aureus Garam + ve.
\end{abstract}

Keywords: Mixed ligands, Metal complexes, Dithiocarbamates (DTCs), Biological activity, Thermal analysis.

\section{INTRODUCTION}

Azo compounds are an interesting materials that have shown a range of applications including; food technology, analytical chemistry, pharmaceutical application and dyeing or textile industry. Their role in coloring approach has been widely investigated and a range of compounds are fabricated ${ }^{1}$. The biological activity of azo-compounds allowed them to be used in the treatment of textile materials, also azo-compounds are well known for their medicinal importance and have shown a variety of applications as antitumor, antibacterial, antiseptics and antineoplastics ${ }^{2}$. Variety of ligands

This is an Open Access article licensed under a Creative Commons Attribution-Non Commercial-Share Alike 4.0 International License (https://creativecommons.org/licenses/by-nc-sa/4.0/), which permits unrestricted Non Commercial use, distribution and reproduction in any medium, provided the original work is properly cited. 
type Schiff-base and their metal complexes have been isolated, these compounds have very flexible and diverse structures, therefore their properties have been studied ${ }^{3}$. Dithiocarbamates (DTCs) are class of organic compounds that are capable to chelate to metal ions ${ }^{4,5}$. DTCs compounds have a significant role in coordination chemistry. This may due to the metal ion stabilization ability in many oxidation states, and permitting the metal ion to implement its desirable structure ${ }^{6}$. DTCs have shown a significant biological activity including their role as antibacterial, antitumor and antifungal agents. They have other potential applications in materials science and supramolecular chemistry ${ }^{7,8}$. In our research, we report here the preparation of mixed azo-linked Schiff-base and DTCs ligands and their metal(II) dithiocarbamate complexes.

\section{EXPERIMENTAL}

All chemicals in this work are commercially available and used as received.Solvents were distilled using appropriate protocol before use.

\section{Physical measurements}

Elemental micro-analyses (carbon, hydrogen, nitrogen and sulphur) for ligand and its metal complexes were conducted on a Euro EA 3000. Electrothermal Stuart SMP40 apparatus was used to record melting points. FT-IR spectra were recorded as potassium bromide discs with a Shimadzu 8300s in the range $4000-400 \mathrm{~cm}^{-1}$ and as Csl discs in the range $400-200 \mathrm{~cm}^{-1}$. UV-Vis spectra were obtained with $10-3 \mathrm{M}$ solutions between 200-1100 nm in dimethylsulfoxide (DMSO) spectroscopic grade solvent at $25{ }^{\circ} \mathrm{C}$ using a Perkin-Elmer spectrophotometer Lambda. TGA was carried out using a STA PT-1000 Linseis. NMR spectra ( $\left.{ }^{1} \mathrm{H}-\mathrm{NMR}\right)$ were acquired in DMSO$\mathrm{d}_{6}$ and $\mathrm{CDCl}_{3}$ using a Brucker-400 $\mathrm{MHz}$ and a Brucker-300 with tetramethy Isilane (TMS). A Shimadzu (A.A) $680 \mathrm{G}$ atomic absorption spectrophotometer was implemented to determine metal content in complexes. Conductivity measurements were performed using a Jenway 4071 digital conductivity meter with DMSO solutions at room temperature. Chloride was determined using potentiometer titration method on a (686-Titro processor-665 Dosimat-Metrohm Swiss).A magnetic susceptibility balance (Sherwood Scientific) was used to determine magnetic moments of complexes.

\section{Synthesis Preparation of the precursor}

The compound was prepared according to the literature ${ }^{9,10}$ 1-naphthyl amine $(1 \mathrm{~g}, 6.98 \mathrm{mmol})$ was dissolved in $\mathrm{H}_{2} \mathrm{O}(10 \mathrm{ml})$ and hydrochloric acid conc. (2.14 ml, $60.98 \mathrm{mmol})$ mixture with stirring, a clear solution was obtained. Temperature of (0-5) ${ }^{\circ} \mathrm{C}$ have been kept, then aqueous solution of sodium nitrite $(0.48 \mathrm{~g}, 6.98 \mathrm{mmol})$ dissolved in $(5 \mathrm{ml})$ water, was dropwise slowlyadded, keeping the temperature below $5^{\circ} \mathrm{C}$, followed by mixture stirring for $1 \mathrm{~h}$, using ice bath, then little amount of urea was added, the $\mathrm{pH}$ was adjusted to 6-7 using sodium acetate [solution(1)]. $\mathrm{H}_{2} \mathrm{NC}_{6} \mathrm{H}_{4} \mathrm{OH}(0.762 \mathrm{~g}, 6.98$ $\mathrm{mmol}$ ) was dissolved in $12 \mathrm{ml} \mathrm{KOH} 10 \mathrm{mmol}$ aqueous solution, cooled by ice bathto (0-5) ${ }^{\circ} \mathrm{C}$ solution(2). Gradually the last solution was mixed with cooling with (solution1), the mixture resulted was stir redat (0-5) ${ }^{\circ} \mathrm{C}$ continually for $2 \mathrm{~h}$, the precipitate resulted was then filtered using acidification, cold $\mathrm{H}_{2} \mathrm{O}$ used to wash several times after drying, a brown solid precipitate was obtained, Yield:1.35 g (73.7\%), melting point $132^{\circ} \mathrm{C}$.

\section{Synthesis of free ligands Preparation of [HL']}

The compound was prepared according to the literature ${ }^{12}$. A solution of the derivative[2amino-6-(naphthalen-1-yldiazenyl)phenol] (1g, 3.798 $\mathrm{mmol})$ in $25 \mathrm{ml}$ ethanol was mixed with $(0.566 \mathrm{~g}$, $3.798 \mathrm{mmol})$ of $\left(\mathrm{CH}_{3}\right)_{2} \mathrm{NC}_{6} \mathrm{H}_{4} \mathrm{CHO}$ dissolved in $(10 \mathrm{ml})$ ethanol. After adding glacial acetic acid (3-5) drops, the mixture resulted was refluxed for $2 \mathrm{~h}$, filtered off, and after washing by ethanol and drying; it was obtained a light brown product. The product solid was recrystallized using EtOH. Yield:1.23 g, $82.5 \%$, melting point $\left(190-192{ }^{\circ} \mathrm{C}\right)$.

\section{Preparation of $\left[\mathrm{L}^{2}\right]$}

The compound was prepared according to the literature ${ }^{13}$. Ethanolic solutionof $\mathrm{KOH}(1.32 \mathrm{~g}$, $23.6 \mathrm{mmol}, 4 \mathrm{eq}$ ) was added to solution of diphenyl amine (1g, $5.90 \mathrm{mmol})$ dissolved in $(10 \mathrm{~mL})$ ethanol. The resulted mixture was stirred keeping the temperature at (0-5), dropwise with stirring it was added carbon disulphide solution(1.34 g, $17.7 \mathrm{mmol}$, 3eq) keeping the temperatureat $0{ }^{\circ} \mathrm{C}$ for 2 hours. The solid DTCS yellow salt was obtained, Yield :1.48 g, $88.6 \%$. Melting point $\left(238-240{ }^{\circ} \mathrm{C}\right)$. 


\section{Synthesis of complexes}

A one pot approach reported in ${ }^{14}$ was used to prepare the mixed ligand metal complexes.

\section{Preparation of $\left[\mathrm{Coll}\left(\mathrm{HL}^{1}\right)\left(\mathrm{L}^{2}\right)\left(\mathrm{H}_{2} \mathrm{O}\right)_{2}\right]$}

To a mixture of $\mathrm{HL} 1(0.2 \mathrm{~g}, 0.506 \mathrm{mmol})$ dissolved in $(10 \mathrm{ml})$ was added $(0.0568 \mathrm{~g}$, $1.0139 \mathrm{mmol}$ ) of potassium hydroxide dissolved in $10 \mathrm{ml}$ ethanol. While, the solution was allowed to stirring, a mixture of Coll salt $(0.120 \mathrm{~g}, 0.506$ $\mathrm{mmol})$ in $10 \mathrm{ml}$ ethanol with $(0.143 \mathrm{~g}, 0.506 \mathrm{mmol})$ of dithocarbamte ligand $\left(L^{2}\right)$ was added to the above solution. The reaction mixture was kept stirring for two $\mathrm{h}$, during which time agreen product was filtered off. Washed with absolute ethanol and recrystallized from ethanolto give the pure product. Yield: $0.187 \mathrm{~g}$, $50.33 \%$, (Dec.over 320).

\section{Preparation of $\mathrm{Ni}(\mathrm{II}), \mathrm{Zn}$ (II) and $\mathrm{Cd}$ (II) complexes}

An analogues method to that reported for the synthesis of Coll complex was implemented to prepare $\mathrm{Ni}(\mathrm{II}), \mathrm{Zn}(\mathrm{II})$, and $\mathrm{Cd}(\mathrm{II})$ mixed ligands complexes. Table 1 displays the physical properties of the complexes and their reactant amount.

\section{RESULTS AND DISCUSSION}

\section{Synthesis}

The precursor was obtained using a standard azo dye approach. The reaction of naphthyl amine diazonium salt with 2-amino-phenole in a 1:1 mole ratio in water solvent gave the required compound, see Scheme 1. Two sorts of ligands were prepared; (i) Azo-linked Schiff-base ligand, which isolated by reaction of the precursor with $\left(\mathrm{CH}_{3}\right)_{2} \mathrm{NC}_{6} \mathrm{H}_{4} \mathrm{CHO}$ and (ii) DTCs ligand that obtained from the reaction of $\left(\mathrm{C}_{6} \mathrm{H}_{5}\right)_{2} \mathrm{NH}$ with carbon disulphide using $\mathrm{KOH}$ base (Schemes 2 and 3 ). The complexes were prepared by mixing the ligands with the metal salts in a 1:1:1 mole ratio (Scheme 4). A range of analytical and spectroscopic techniques were used to confirm the entity of compounds including; CHNS, FT-IR, UV-Vis, magnetic susceptibility and ${ }^{1} \mathrm{H}-\mathrm{NMR}$ spectra. The infra-red spectrum of $\left[\mathrm{HL}^{1}\right]$, Fig. (1), exhibited bands at 3423 and $2978 \mathrm{~cm}^{-1}$ attributed to the $\mathrm{OH}$ phenolic group ${ }^{15,16}$ and $\mathrm{v}(\mathrm{C}-\mathrm{H})$ aliphatic stretching, respectively. Bands related to $\mathrm{v}(\mathrm{C}=\mathrm{N})$ imine and $\mathrm{v}(\mathrm{C}-\mathrm{N})$ are observed at 1630 and $1257 \mathrm{~cm}^{-1}$, respectively. The formation of Schiff-base ligand can be indicated by the absence of amine
$\left(\mathrm{NH}_{2}\right)$ and aldehydic $\mathrm{CHO}$ bands and appearance of the new imine $(\mathrm{C}=\mathrm{N})$ band in the ligand spectrum ${ }^{17-19}$.

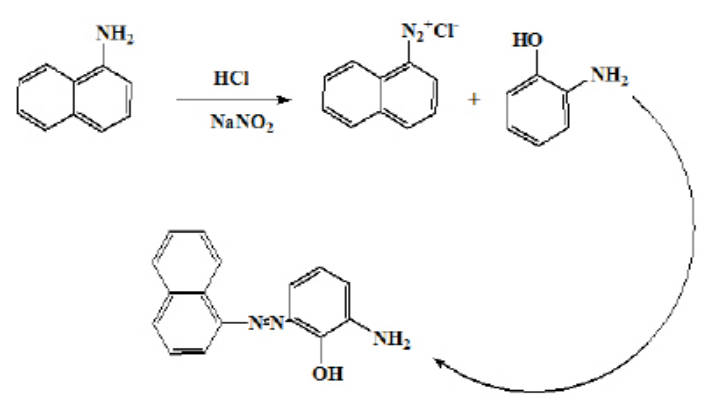

Scheme 1. Preparation path for Precursor

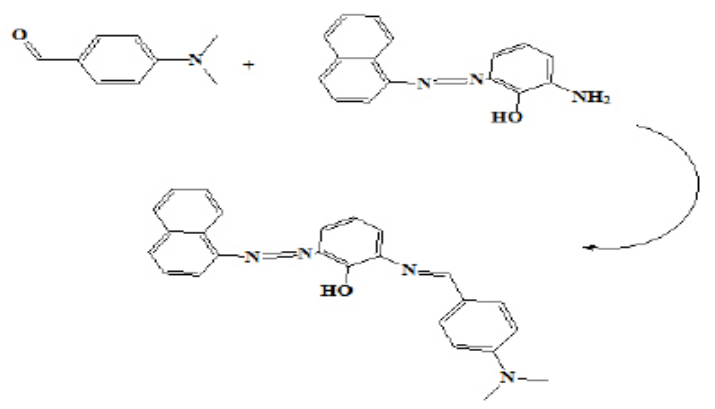

Scheme 2. Preparation route for ligand[HL']<smiles>O=C=[Te]C(=O)O</smiles>

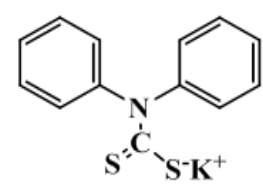

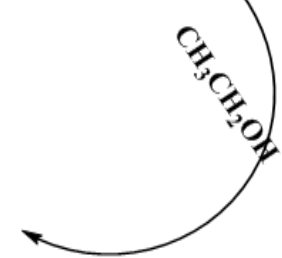

Scheme 3. Preparation route of ligand $\left[L^{2}\right]$

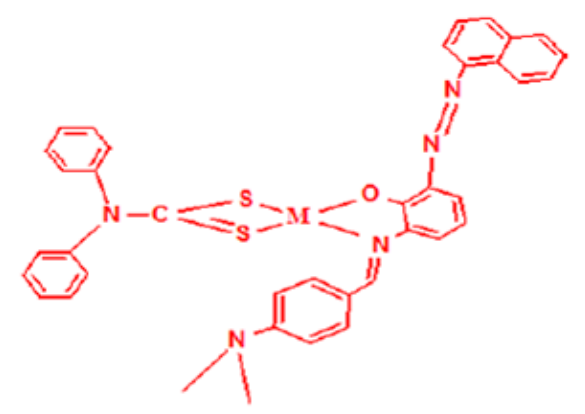

Where $\mathrm{M}=\mathrm{Co}^{\mathrm{II}}, \mathrm{Ni}^{\mathrm{II}}, \mathrm{Zn}^{\mathrm{II}}$ and $\mathrm{Cd}^{\mathrm{II}}$

Scheme 4. Structure of mixed ligand complexes of mixed ligand complexes 
Table1: Melting points, yields, metal salts quantities and colours of ligands and thier complexes

\begin{tabular}{lccccc}
\hline Compound & Dec. $\left({ }^{\circ} \mathrm{C}\right)$ & $\begin{array}{c}\text { Weight of } \\
\text { metal salt(g) }\end{array}$ & $\begin{array}{c}\text { Weight of } \\
\text { complex }(\mathrm{g})\end{array}$ & Yield (\%) & Colour \\
\hline$\left[\mathrm{Co}\left(\mathrm{L}^{1}\right)\left(\mathrm{L}^{2}\right)\left(\mathrm{H}_{2} \mathrm{O}\right)_{2}\right]$ & Over 320* & 0.123 & 0.188 & 51 & Light green \\
{$\left[\mathrm{Ni}\left(\mathrm{L}^{1}\right)\left(\mathrm{L}^{2}\right)\right]$} & Over 320* & 0.121 & 0.172 & 49 & Green \\
{$\left[\mathrm{Zn}\left(\mathrm{L}^{1}\right)\left(\mathrm{L}^{2}\right)\left(\mathrm{H}_{2} \mathrm{O}\right)_{2}\right]$} & Over 320* & 0.07 & 0.148 & 40 & Dark brown \\
$\mathrm{K}_{2}\left[\mathrm{Cd}\left(\mathrm{L}^{1}\right)\left(\mathrm{L}_{2}\right) \mathrm{Cl}_{2}\right]$ & Over 320* & 0.103 & 0.185 & 41 & light yellow \\
\hline
\end{tabular}

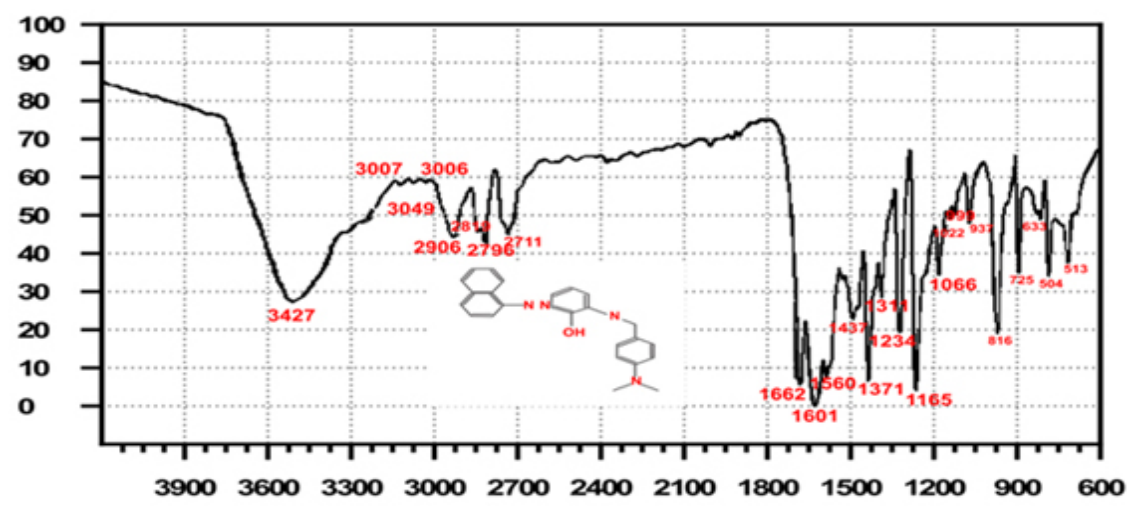

Fig. 1. FT-IR spectrum of ligand $\left[\mathrm{HL}^{1}\right]$

Band related to stretching $\mathrm{v}(\mathrm{N}=\mathrm{N})$ azo group are detected at $1460 \mathrm{~cm}^{-1} 16,20$. The FT-IR spectrum of [ $\left.\mathrm{L}^{2}\right]$ is displayed in Fig.(2). The $\mathrm{u}(\mathrm{C}-\mathrm{N})$ of $\left(\mathrm{N}-\mathrm{CS}_{2}\right)$ moiety shows a band at $1471 \mathrm{~cm}^{-121}$. The spectrum indicates a couple of new bands at (894) and (1047) $\mathrm{cm}^{-1}$, which designated to $v_{s}\left(\mathrm{CS}_{2}\right)$ and vas $\left(\mathrm{CS}_{2}\right)$ respectively 22 . The characteristic bands are summarised in (Table 3 ). The ${ }^{1} \mathrm{H}-\mathrm{NMR}$ spectrum of $\left[\mathrm{HL}^{1}\right]$, Fig.(7), displays peak related to the azomethine group at $v=10.1 \mathrm{ppm}(\mathrm{H}, \mathrm{s}, \mathrm{N}=\mathrm{C}-\mathrm{H})^{23}$. Chemical shift at $v=10.809 \mathrm{ppm}(\mathrm{OH}, \mathrm{S}, \mathrm{H})$ correlated to the phenolic proton. The spectrum indicated that the non-equivalent two $\mathrm{CH}_{3}$ groups appeared at $\mathrm{v}=2.2$ and 3.3-3.4ppm $\left(2 \mathrm{CH}_{3}, \mathrm{~S}, 6 \mathrm{H}\right)$. That may probably resulted from the position alternation of the two $\mathrm{CH}_{3}$ groups in the proposed structure of the molecule. An averaged symmetrical spectrum may resulted from rapid rotation process. On the other hand, two non-equivalent conformations may resulted from the slow rotation. The ${ }^{1} \mathrm{H}-\mathrm{NMR}$ spectrum of $\left[\mathrm{L}^{2}\right]$ is depicted in (Fig.8). The spectrum shows peaks at $v=5.561 \mathrm{ppm}(2 \mathrm{H}, \mathrm{m})\left(\mathrm{C} 1,1^{`}, 5,5^{`}-\mathrm{H}\right), \quad v=6.789$ -

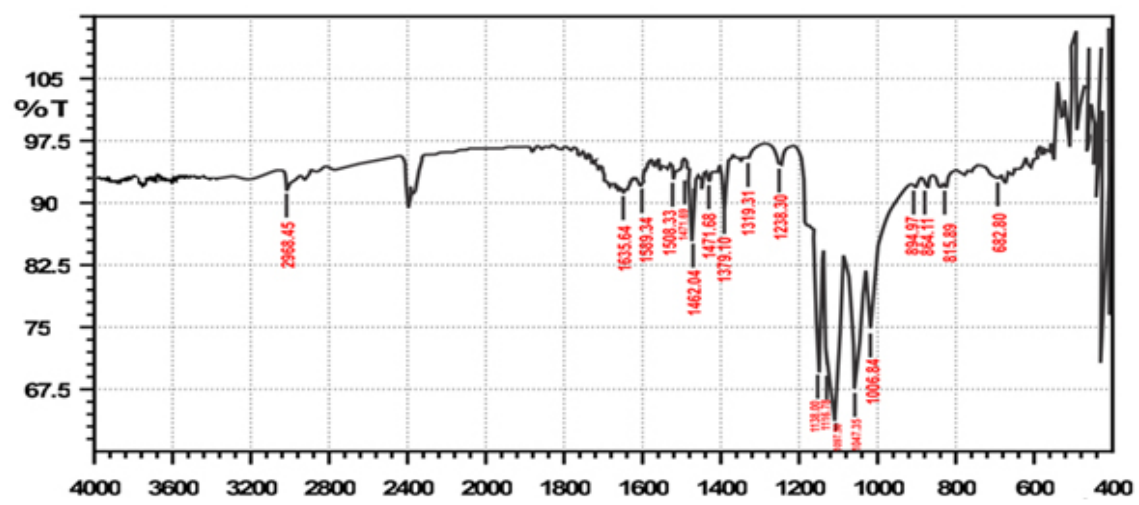

Fig. 2. FT-IR spectrum of ligand $\left[L^{2}\right]$ 
$6.805 \mathrm{ppm}(2 \mathrm{H}, \mathrm{m})\left(\mathrm{C} 3,3^{\prime}-\mathrm{H}\right)$ and $\mathrm{v}=7.685-7.694$ ppm $(2 \mathrm{H}, \mathrm{m})\left(\mathrm{C} 2,2^{\prime}, 4,4^{\prime}-\mathrm{H}\right)$ attributed to the aromatic ring protons. The complexes are air stable solid. The entity of new complexes was confirmed by elemental analysis, FT-IR, electronic spectra and magnetic susceptibility. The analytical data (Table 2) support the proposed formulae.The molar conductance of the complexes in DMSO solvents is indicative ofnon-electrolyte and 1:2 electrolyte behaviour ${ }^{24,25}$.

Table 2: Colours, Yields, (C, H, N, S) analysis and chloride content values for ligands and complexes

\begin{tabular}{|c|c|c|c|c|c|c|c|c|c|}
\hline \multirow[t]{2}{*}{ Compound } & \multirow[t]{2}{*}{ M.wt } & \multirow[t]{2}{*}{ Yield \% } & \multirow[t]{2}{*}{ colour } & \multirow[b]{2}{*}{$\mathrm{M} \%$} & \multicolumn{5}{|c|}{ Found (Calc.) \% } \\
\hline & & & & & C & $\mathrm{H}$ & $\mathrm{N}$ & $S$ & $\mathrm{Cl}$ \\
\hline $\mathrm{HL}^{1}$ & 394.47 & 82.5 & Light brown & - & $\begin{array}{c}75.74 \\
(76.12)\end{array}$ & $\begin{array}{c}5.38 \\
(5.62)\end{array}$ & $\begin{array}{l}14.04 \\
(14.2)\end{array}$ & & \\
\hline $\mathrm{L}^{2}$ & 283.46 & 88.6 & yellow & - & $\begin{array}{c}53.38 \\
(55.08)\end{array}$ & $\begin{array}{c}3.38 \\
(3.56)\end{array}$ & $\begin{array}{c}4.65 \\
(4.94)\end{array}$ & $\begin{array}{c}22.34 \\
(22.63)\end{array}$ & \\
\hline$\left[\mathrm{Co}\left(\mathrm{L}^{1}\right)\left(\mathrm{L}^{2}\right)\left(\mathrm{H}_{2} \mathrm{O}\right)_{2}\right]$ & 732.78 & 51 & Light green & $\begin{array}{c}7.12 \\
(8.04 .)\end{array}$ & - & - & - & - & - \\
\hline$\left[\mathrm{Ni}\left(\mathrm{L}^{1}\right)\left(\mathrm{L}^{2}\right)\right]$ & 696.51 & 49 & Light green & $\begin{array}{c}7.55 \\
(8.42 .)\end{array}$ & - & - & - & - & - \\
\hline$\left[\mathrm{Zn}\left(\mathrm{L}^{1}\right)\left(\mathrm{L}^{2}\right)\left(\mathrm{H}_{2} \mathrm{O}\right)_{2}\right]$ & 739.23 & 40 & Dark brown & $\begin{array}{c}8 \\
(8.84 .)\end{array}$ & - & - & - & - & - \\
\hline $\mathrm{K}_{2}\left[\mathrm{Cd}\left(\mathrm{L}^{1}\right)\left(\mathrm{L}^{2}\right) \mathrm{Cl}_{2}\right]$ & 898.33 & 41 & Light yellow & $\begin{array}{c}12.01 \\
(12.51)\end{array}$ & $\begin{array}{c}50 \\
(50.76)\end{array}$ & $\begin{array}{c}3.11 \\
(3.45)\end{array}$ & $\begin{array}{c}6.89 \\
(7.79)\end{array}$ & $\begin{array}{c}7.44 \\
(7.21)\end{array}$ & $\begin{array}{c}7 \\
(7.89)\end{array}$ \\
\hline
\end{tabular}

\section{FTIR and NMR spectra for complexes}

The FTIR spectra of complexes show bands at rang (1606-1639) $\mathrm{cm}^{-1}$ were assigned to of imine $v(\mathrm{C}=\mathrm{N})$ group, with alower frequency shift. This may be related to the engagement of the nitrogen atom of the iminic moiety in the coordination reaction ${ }^{26-28}$. The shift also may explained by delocalisation process of the $\mathrm{d}-10$ (metal electron density) to the ligand (usystem) ${ }^{29,30}$. Spectra for complexes appeared bands at rang (1500-1510) $\mathrm{cm}^{-1}$ that attributed to $\left(\mathrm{N}-\mathrm{CS}_{2}\right)^{21}$. This confirms that the $\mathrm{v}(\mathrm{N}-\mathrm{C})$ double bond character may increase as a consequence of the moving of electrons to the metal centre as a result of coordination to the DTCs ${ }^{22}$. Band located in the range (1454-1469) $\mathrm{cm}^{-1}$ is assigned to $\mathrm{v}(\mathrm{N}=\mathrm{N})$ azo. Finally, the spectra showed new bands in the range (609-673) and (416-489) $\mathrm{cm}^{-1}$ that attributed to $v(\mathrm{M}-\mathrm{N})$ and $v(\mathrm{M}-\mathrm{O})$, respectively. The appearance of these bands supported the involvement of the nitrogen of imin and oxygen phenolic atoms in the coordination of the ligand to the metal centre. These results are in accordance with that reported in literature ${ }^{31,32}$. Bands detected at (1043-1053) and (948-997) $\mathrm{cm}^{-1}$ are due to vas $\left(\mathrm{CS}_{2}\right)$ asymmetric and us $\left(\mathrm{CS}_{2}\right)$ symmetric mode of the DTCsmoiety, respectively. This is in agreement with an anisobidentate chelation mode of the ligand to the metal ion ${ }^{22}$. The anisobidentate mode of chelation of the ligand, may confirmed by thebands observed in the range (302-393) $\mathrm{cm}^{-1}$ which may attributed to $v(\mathrm{M}-\mathrm{S})$ bond $^{33}$. The spectra of Co, see Fig. (3), and Zn complexes exhibited a broad band that assigned to $v(\mathrm{OH})$ of the hydrated water molecule ${ }^{16}$. Table (3) includes the prominent FTIR bands of complexes. The ${ }^{1} \mathrm{H}-\mathrm{NMR}$ spectrum of $\mathrm{K}^{2}\left[\mathrm{Cd}\left(\mathrm{L}^{1}\right)\left(\mathrm{L}^{2}\right) \mathrm{Cl}_{2}\right]$, (Fig. 9), displays peak at $\delta=10.9 \mathrm{ppm}$ related to the proton of the iminicmoiety $(1 \mathrm{H}, \mathrm{s}, \mathrm{N}=\mathrm{C}-\mathrm{H})^{23}$. The chemical shift at $\delta=2.2 \mathrm{ppm}$ that equivalent to six protons assigned to the methyl groups $\left(2 \mathrm{CH}_{3}, \mathrm{~s}, 6 \mathrm{H}\right)$.

\section{UV-Vis Spectral data and magnetic susceptibility of the complexes}

The electronic spectra of the complexes exhibited peaks in the range $262-305 \mathrm{~nm}$ attributed to $\pi \rightarrow \pi^{*}$ transition of the aromatic rings ${ }^{34}$. The spectra of complexes revealed peaks around 349 $\mathrm{nm}$ related to $\left(\mathrm{n} \rightarrow \pi^{*}\right)$ transition of azo moiety. The blue shift recorded may attribute to the energy 

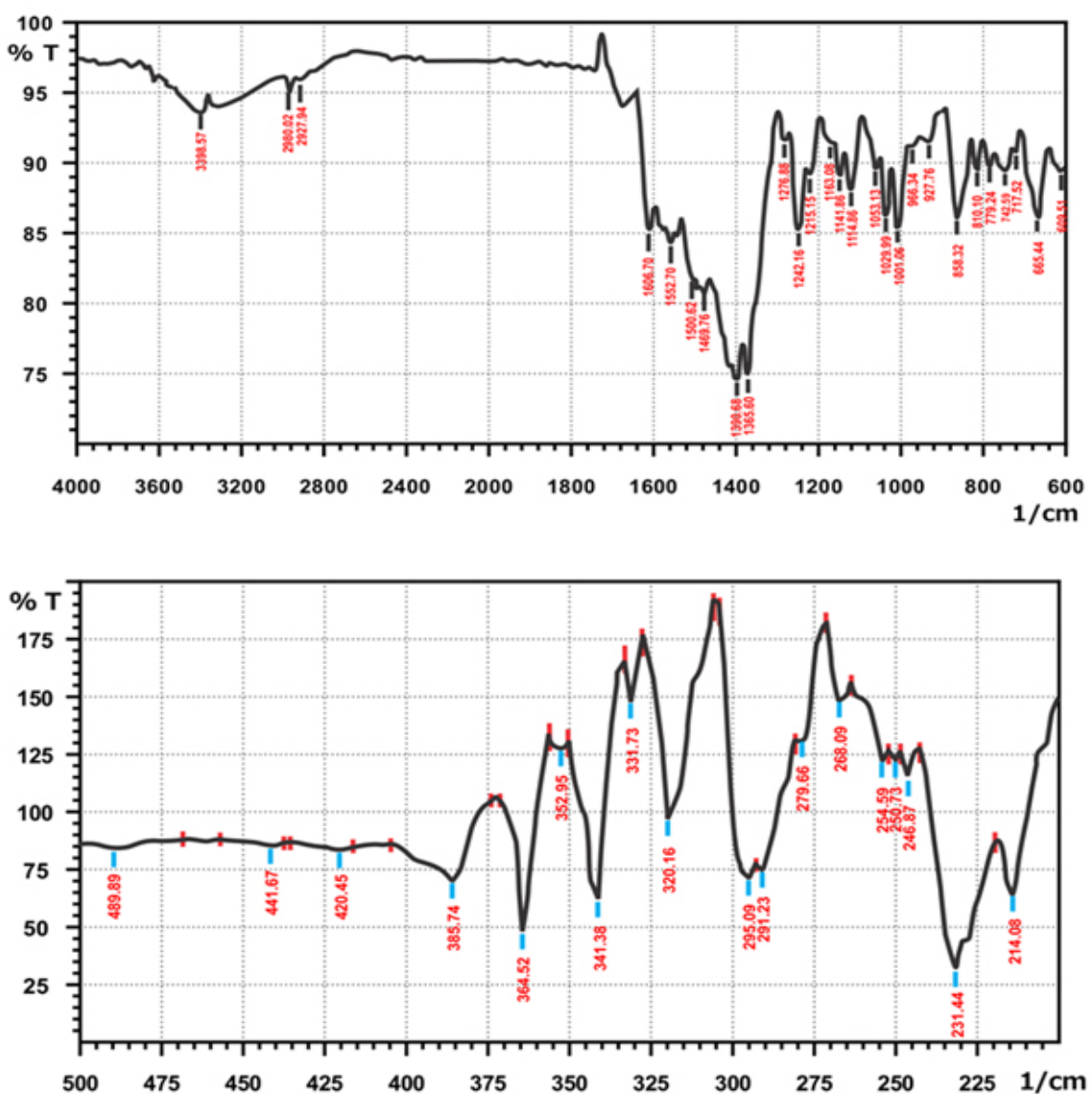

Fig. 3. FT-IR spectrum of $\left[\mathrm{Co}\left(\mathrm{L}^{1}\right)\left(\mathrm{L}^{2}\right)\left(\mathrm{H}_{2} \mathrm{O}\right)_{2}\right]$ complex

Table 3: FT-IR spectral data for ligands and complexes

\begin{tabular}{|c|c|c|c|c|c|c|c|c|c|}
\hline Compound & $\mathrm{v}(\mathrm{C}-\mathrm{H})_{\mathrm{ar}}$ & $v(\mathrm{C}-\mathrm{H})_{\mathrm{ali}}$ & $v(\mathrm{C}=\mathrm{N})_{\mathrm{im}}$ & $(\mathrm{N}-\mathrm{CS} 2)_{\mathrm{di}}$ & $v(\mathrm{~N}=\mathrm{N})_{\mathrm{azo}}$ & $\begin{array}{l}\mathrm{u}(\mathrm{CS} 2)_{\mathrm{as}} \\
\mathrm{u}(\mathrm{CS} 2)_{\mathrm{s}}\end{array}$ & $\begin{array}{l}u(M-N) \\
v(M-O)\end{array}$ & $v(M-S)$ & $v(M-C l)$ \\
\hline $\mathrm{HL}^{1}$ & $\begin{array}{l}3097, \\
3049, \\
3008\end{array}$ & 2906 & 1642 & - & 1437 & - & - & - & - \\
\hline $\mathrm{L}^{2}$ & 2968 & - & - & 1471 & - & $\begin{array}{c}1,047 \\
894\end{array}$ & - & - & - \\
\hline$\left[\mathrm{Co}\left(\mathrm{L}^{1}\right)\left(\mathrm{L}^{2}\right)\left(\mathrm{H}_{2} \mathrm{O}\right)_{2}\right]$ & 2980 & 2927 & 1606 & 1500 & 1469 & $\begin{array}{c}1,053 \\
966\end{array}$ & $\begin{array}{l}665,609 \\
489,420\end{array}$ & $\begin{array}{c}385, \\
320\end{array}$ & - \\
\hline$\left[\mathrm{Ni}\left(\mathrm{L}^{1}\right)\left(\mathrm{L}^{2}\right)\right.$ & 3035 & $\begin{array}{c}29 \\
832 \\
891\end{array}$ & 1639 & 1510 & 1462 & $\begin{array}{c}1,051 \\
993\end{array}$ & $\begin{array}{l}673,619 \\
464,420\end{array}$ & $\begin{array}{l}387, \\
302\end{array}$ & - \\
\hline$\left[\mathrm{Zn}\left(\mathrm{L}^{1}\right)\left(\mathrm{L}^{2}\right)\left(\mathrm{H}_{2} \mathrm{O}\right)_{2}\right]$ & 2981 & 2895 & 1622 & 1506 & 1454 & $\begin{array}{c}1,043 \\
997\end{array}$ & $\begin{array}{c}671 \\
489 \\
457\end{array}$ & $\begin{array}{l}385, \\
302\end{array}$ & - \\
\hline $\mathrm{K}_{2}\left[\mathrm{Cd}\left(\mathrm{L}^{1}\right)\left(\mathrm{L}^{2}\right) \mathrm{Cl}_{2}\right]$ & 3035 & $\begin{array}{c}29 \\
832 \\
889\end{array}$ & 1624 & 1504 & 1458 & $\begin{array}{c}1,050 \\
948\end{array}$ & $\begin{array}{l}621 \\
457 \\
416\end{array}$ & $\begin{array}{c}393, \\
304\end{array}$ & $\begin{array}{l}298, \\
268\end{array}$ \\
\hline
\end{tabular}


change of the conjugated chromophore $\left(\mathrm{n} \rightarrow \pi^{\star}\right)$ and ( $\pi \rightarrow \pi^{*}$ electronic transitions, due to the chelation between metal ions and azo ligand ${ }^{35}$. The spectrum of Coll complex, see (Fig. 6), reveals peaks at 886 and $528 \mathrm{~nm}$ assignable to ${ }^{4} \mathrm{~T}_{1} \mathrm{~g}(\mathrm{~F}) \rightarrow{ }^{4} \mathrm{~T}_{2} \mathrm{~g}(\mathrm{~F})$ ${ }^{4} \mathrm{~T}_{1} \mathrm{~g}(\mathrm{~F}) \rightarrow{ }^{4} \mathrm{~T}_{1} \mathrm{~g}(\mathrm{P})$ transitions respectively whichmay confirm a distorted octahedral structure for $\mathrm{Co}(\mathrm{II})$ complex ${ }^{36-39}$, this result was confirmed by the magnetic moment value $\mu$ eff of 5.07 B.M for the $\mathrm{Co}$ (II)-complex ${ }^{40}$. The Ni(II) complex shows a peak at $617 \mathrm{~nm}$ attributed to ${ }^{1} \mathrm{~A}_{1} \mathrm{~g}(\mathrm{f}) \rightarrow{ }^{1} \mathrm{~A}_{2} \mathrm{~g}(\mathrm{~F})$, revealing a distorted square planar arrangement about $\mathrm{Ni}$ atom. This result was confirmed by the diamagnetic moment behavior of the $\mathrm{Ni}(\mathrm{II})$-complex ${ }^{40}$. The spectra of $\mathrm{Zn}(\mathrm{II})$ and $\mathrm{Cd}(\mathrm{II})$ compounds revealed peaks attributed to ligand field $\pi \rightarrow \pi^{*}$ and $\mathrm{M} \rightarrow \mathrm{L}$ charge transfer ${ }^{41}$. These data along with other analytical results indicated that the $\mathrm{Zn}$ (II) and $\mathrm{Cd}$ (II) complexes adopt octahedral arrangement about metal centre ${ }^{42}$. The six-coordinate number for the $\mathrm{Zn}$ (II) and $\mathrm{Cd}(\mathrm{II})$ compounds may be due to sort of ligands that surrounding metal centre and their steric and electronic interaction that occurred upon complex formation ${ }^{43}$. The electronic data of the complexes are tabulated in (Table 5).

\section{Thermal analysis}

The thermogram chart indicated the stability of $\left[\mathrm{Co}\left(\mathrm{L}^{2}\right)\left(\mathrm{L}^{4}\right)\left(\mathrm{H}_{2} \mathrm{O}\right)_{2}\right]$ up to $97{ }^{\circ} \mathrm{C}$, see (Fig. 10). peak detected at $297^{\circ} \mathrm{C}$ may due to the loss of $\left(\mathrm{HCN}, 2 \mathrm{H}_{2} \mathrm{O}, \mathrm{NO}\right.$ and $\left.\mathrm{CS}_{2}\right)$ moieties, (obs. $=4.86 \mathrm{mg}$, $23.15 \%$; Calc. $=4.85 \mathrm{mg} .23 .1 \%$. While second step at $(594){ }^{\circ} \mathrm{C}$ may refers to the loss of $\left(\mathrm{C}_{6} \mathrm{H}_{6}\right.$ and $\left.\mathrm{N}_{2}\right)$ fragment, (det. $=3.06 \mathrm{mg}, 14.56 \%$; Calc. $=3.07 \mathrm{mg} .14 .46 \%$ ). The final residue from the compound which may assigned to the ( $\mathrm{Co}, \mathrm{CH}_{3} \mathrm{NCH}_{3}, 2 \mathrm{C}_{6} \mathrm{H}_{4}, \mathrm{C}_{6} \mathrm{H}_{3}$, and $\mathrm{C}_{10} \mathrm{H}_{7}$ ), Calc. $=13.1 \mathrm{mg} .62 .4 \%$ ). The dithiocarbamates analysis thermogram showed peaks at 97,310 , 320,398 and 594 may assigned to an exo and endo thermal decomposition process. The peak at 320 (exothermic) may due to combustion process of the organic ligand part(in an argon atmosphere). While metal-ligand bond breaking may signified by

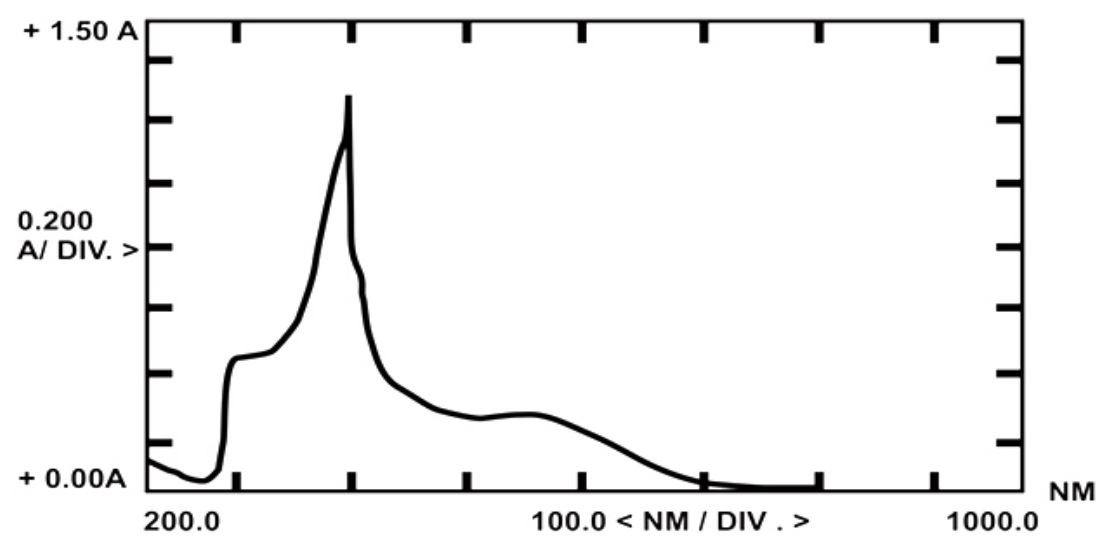

Fig. 4. Electronic spectrum of $\left[\mathrm{HL}^{1}\right]$

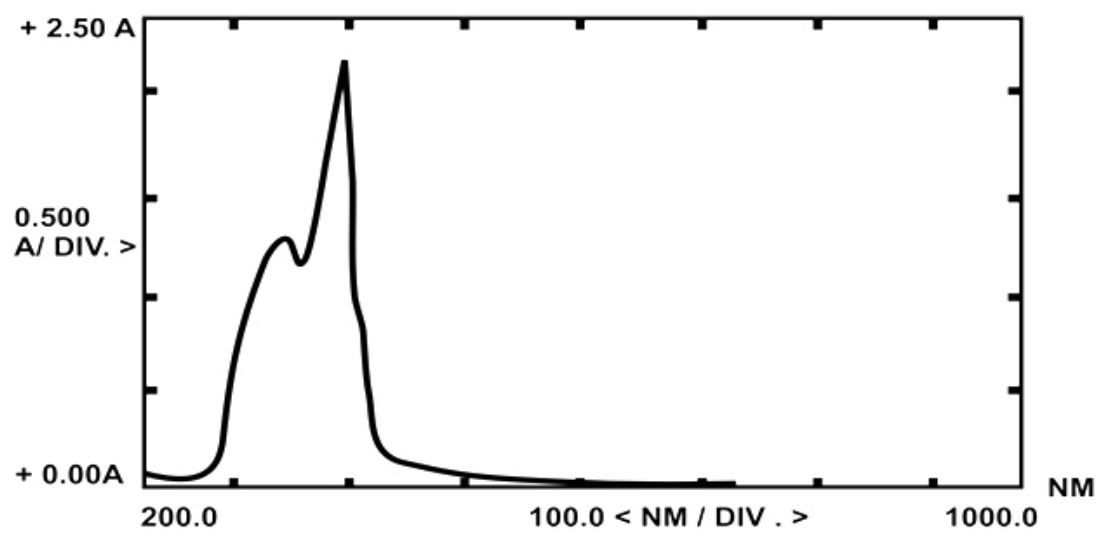

Fig. 5. Electronic spectrum of $\left[\mathrm{L}^{2}\right]$ 


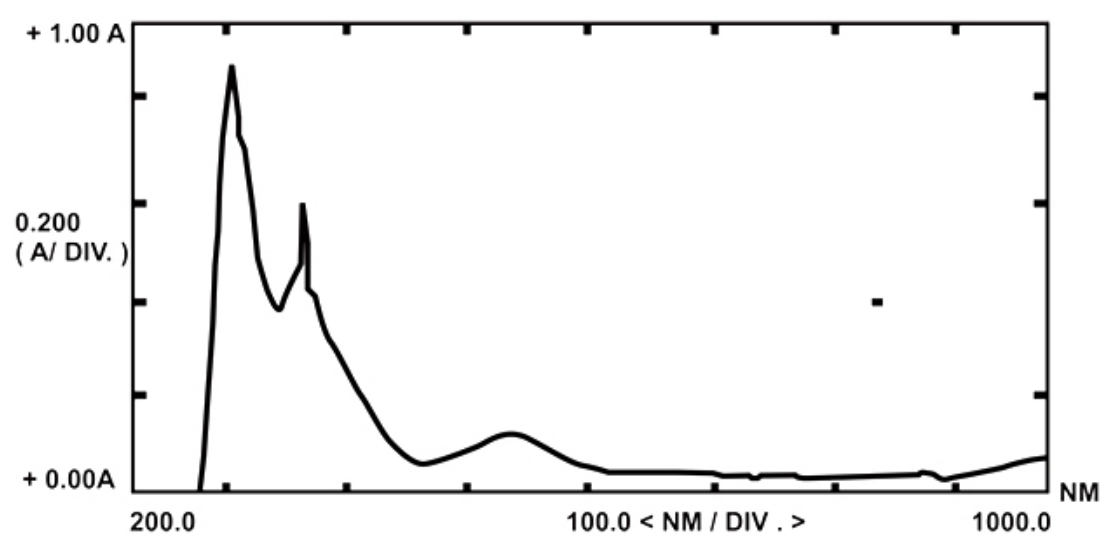

Fig. 6. Electronic spectrum of $\left[\mathrm{Co}\left(\mathrm{L}^{1} \mathrm{~L}^{2}\right)\left(\mathrm{H}_{2} \mathrm{O}\right)_{2}\right]$

Table 4: Electronic spectral dataof complexes in DMSO solutions

\begin{tabular}{lccccc}
\hline Compound & $\begin{array}{c}\text { Wave number Wave number } \\
\lambda n m\end{array}$ & $\begin{array}{c}\text { (cmax molar } \\
\left(\mathrm{cm}^{-1}\right)\end{array}$ & $\begin{array}{c}\text { Assignment } \\
\mathrm{cm}^{-1}\end{array}$ & $\begin{array}{c}\text { Suggested } \\
\text { structure }\end{array}$ \\
\hline$\left[\mathrm{Co}\left(\mathrm{L}^{1}\right)\left(\mathrm{L}^{2}\right)\left(\mathrm{H}_{2} \mathrm{O}\right)_{2}\right]$ & 287 & 34843 & 828 & $\mathrm{n} \rightarrow \pi^{*}, \pi \rightarrow \pi^{*}$ & Distorted \\
& 348 & 28735 & 559 & $\mathrm{C} . \mathrm{T}$ & octahedral \\
& 528 & 19047 & 107 & ${ }^{4} \mathrm{~T}, \mathrm{~g}(\mathrm{~F}) \rightarrow{ }^{4} \mathrm{~T}_{1} \mathrm{~g}(\mathrm{P})$ & \\
& 886 & 11286 & 16 & ${ }^{4} \mathrm{~T}_{1} \mathrm{~g}(\mathrm{~F}) \rightarrow{ }^{4} \mathrm{~T}_{2} \mathrm{~g}(\mathrm{~F})$ & \\
{$\left[\mathrm{Ni}\left(\mathrm{L}^{1}\right)\left(\mathrm{L}^{2}\right)\right]$} & 295 & 33898 & 351 & $\mathrm{n} \rightarrow \pi^{*}, \pi \rightarrow \pi^{*}$ & Square \\
& 348 & 28735 & 551 & $\mathrm{C} . \mathrm{T}$ & planar \\
& 617 & 16207 & 26 & ${ }^{1} \mathrm{~A}_{1} \mathrm{~g}(\mathrm{~F}) \rightarrow{ }^{1} \mathrm{~A}_{2} \mathrm{~g}(\mathrm{~F})$ & \\
{$\left[\mathrm{Zn}\left(\mathrm{L}^{1}\right)\left(\mathrm{L}^{2}\right)\left(\mathrm{H}_{2} \mathrm{O}\right)_{2}\right]$} & 262 & 38167 & 33 & $\mathrm{n} \rightarrow \pi^{*}, \pi \rightarrow \pi^{*}$ & Distorted \\
& 349 & 28653 & 124 & $\mathrm{C} . \mathrm{T}$ & octahedral \\
$\mathrm{K} \mathrm{K}_{2}\left[\mathrm{Cd}\left(\mathrm{L}^{1}\right)\left(\mathrm{L}^{2}\right) \mathrm{Cl}_{2}\right]$ & 305 & 32786 & 811 & $\mathrm{n} \rightarrow \pi^{*}, \pi \rightarrow \pi^{*}$ & Distorted \\
& 346 & 28901 & 1113 & $\mathrm{C} . \mathrm{T}$ & octahedral \\
\hline
\end{tabular}

Table 5: Biological activity of compounds

\begin{tabular}{lcccc}
\hline & \multicolumn{2}{c}{ Gram negative } & \multicolumn{2}{c}{ Gram negative } \\
\cline { 2 - 5 } Compounds & \multicolumn{1}{c}{ Bacillus stubtilis Staphylococcus aureus $(G+)$} & Escherichia coli(G-) & Enterobacter $(G-)$ \\
\cline { 2 - 5 } Control & - & - & - & - \\
$\mathrm{HL}^{1}$ & - & - & - & - \\
$\mathrm{L}^{2}$ & 22 & 12 & - & - \\
{$\left[\mathrm{Co}\left(\mathrm{L}^{1}\right)\left(\mathrm{L}^{2}\right)\left(\mathrm{H}_{2} \mathrm{O}\right)_{2}\right]$} & 12 & - & - & - \\
{$\left[\mathrm{Ni}\left(\mathrm{L}^{1}\right)\left(\mathrm{L}^{2}\right)\right]$} & - & - & - & - \\
{$\left[\mathrm{Zn}\left(\mathrm{L}^{1}\right)\left(\mathrm{L}^{2}\right)\left(\mathrm{H}_{2} \mathrm{O}\right)_{2}\right]$} & 13 & - & - & - \\
$\mathrm{K}_{2}\left[\mathrm{Cd}\left(\mathrm{L}^{1}\right)\left(\mathrm{L}^{2}\right) \mathrm{Cl}_{2}\right]$ & 14 & - & - & - \\
\hline
\end{tabular}

endothermic peaks at $97,310,398$ and $594{ }^{\circ} \mathrm{C}^{44,45}$. Biological activity

The synthesized ligands and its complexes were screened for their biological activity against some bacterial strains (Escherichia coli and Enterobacter (G-) Bacillus stubtilis and Staphylococcus aureus $(G+)$. The involvement of dimethylsulphoxide in the bacterial test was confirmed by individual tests that 
conducted with the DMSO alone that indicated no activity towards any bacterial species ${ }^{46}$. The measured size of inhibition zones against growth of different microorganisms are summarised in that displays the effect of the prepared compounds on bacterial species. From collected data, it is clear that, compared with the free ligands, the ligands $\left(\mathrm{HL}^{1}\right.$ and $L^{2}$ ) showed no antimicrobial activity against Escherichia coli and Enterobacter. Hence, formation of complexes enhances the antimicrobial activity.
Such increased activity of complexes may be related to the chelation theory ${ }^{33}$. Therefore, the chelation decreases the polarity of the metal atom that resulted in the partial sharing of its positive charge with donor group and possible $\pi$-electron delocalisation over the whole ring. Zinc and cadmium complexes showed almost the higher antibacterial activity, compared with other compounds. This due to to their molecular weight and their electronic configuration ( ${ }^{10}$ system), compared with other metal complexes (Figures.11-14) ${ }^{47,48}$.

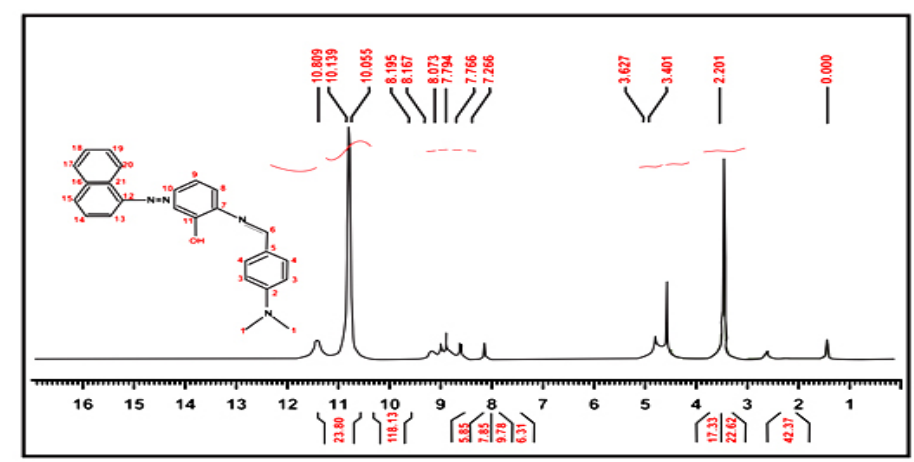

Fig. 7. ${ }^{1} \mathrm{H}-\mathrm{NMR}$ spectrum of ligand $\mathrm{HL}^{1}$ in $\mathrm{CDCl}_{3}$

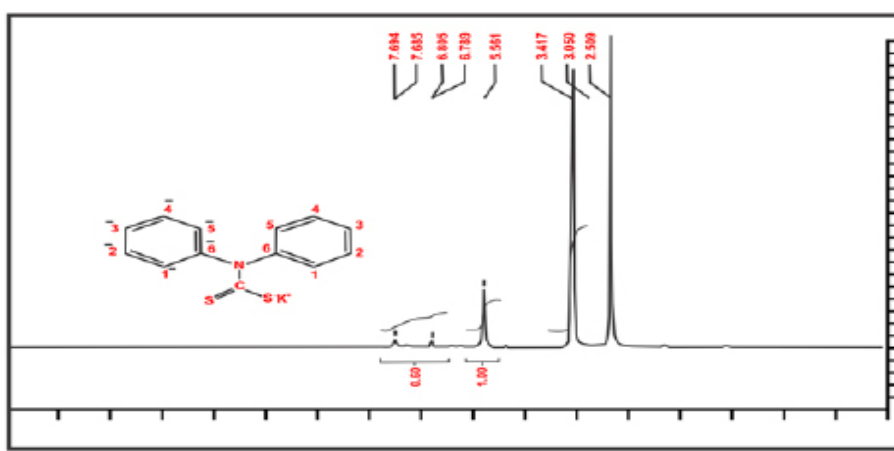

Fig. 8. ${ }^{1} \mathrm{H}-\mathrm{NMR}$ spectrum of ligand $L^{2}$ in DMSO- $\mathrm{d}_{6}$

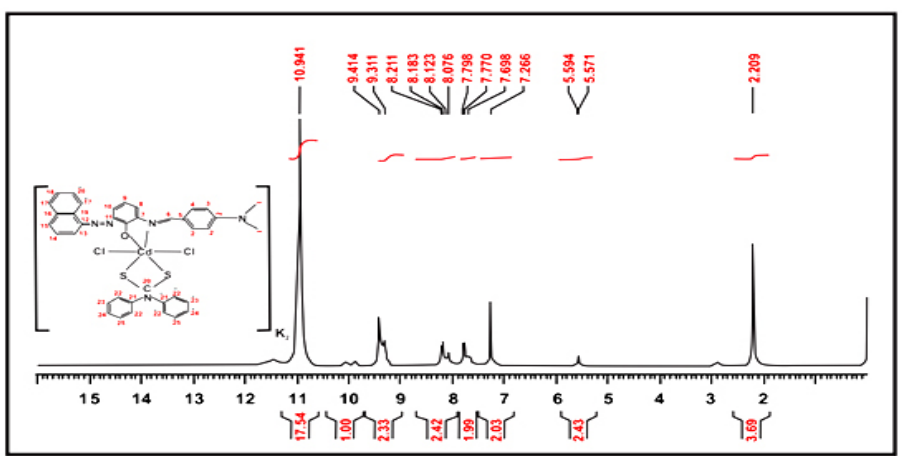

Fig. 9. ' $\mathrm{H}-\mathrm{NMR}$ spectrum of $\mathrm{K}_{2}\left[\mathrm{Cd}\left(\mathrm{L}^{1}\right)\left(\mathrm{L}^{2}\right) \mathrm{Cl}_{2}\right]$ in $\mathrm{CDCl}_{3}$ 


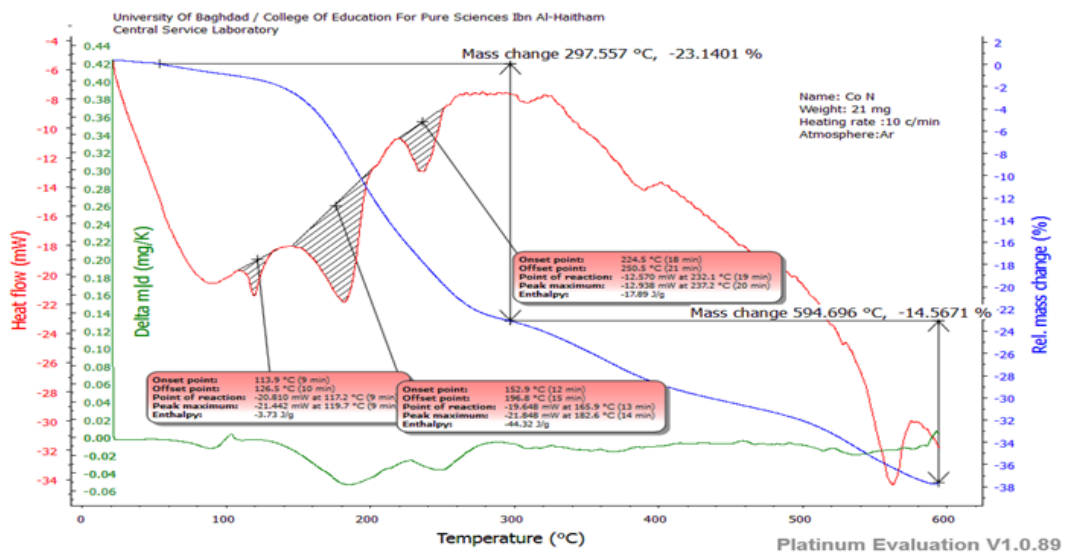

Fig. 10. (TGA/ DTA and DSC) thermogram of $\left[\mathrm{Co}\left(L^{1}\right)\left(\mathrm{L}^{2}\right)\left(\mathrm{H}_{2} \mathrm{O}\right)_{2}\right]$ in an argon atmosphere

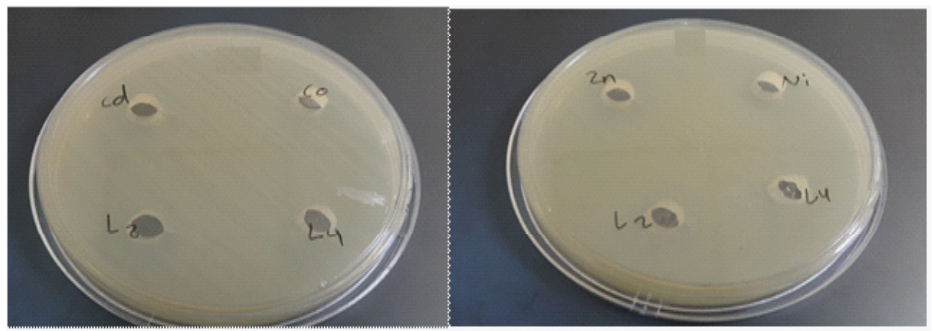

Fig. 11. The effect of $L^{1} L^{2}$ and its complexes on Escherichia coli
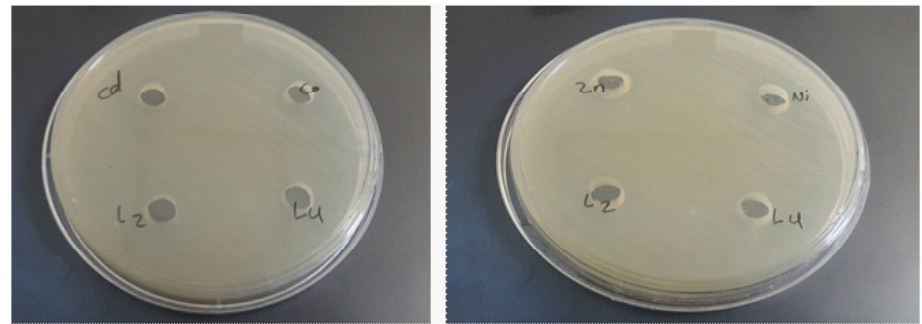

Fig. 12. The effect of $L^{1} L^{2}$ and its complexes on Enterobacter

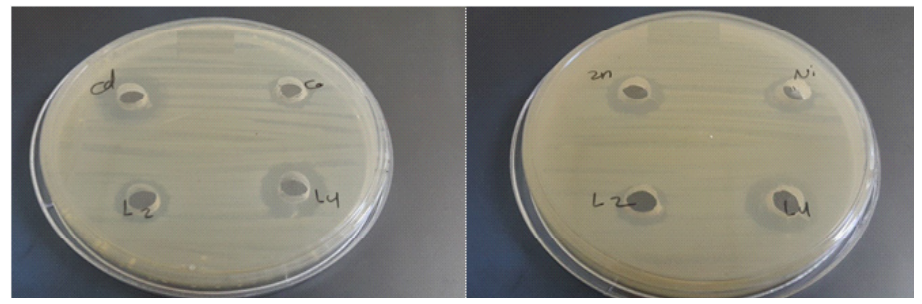

Fig. 13. The effect of $L^{1} L^{2}$ and its complexes on Bacillus stubtilis

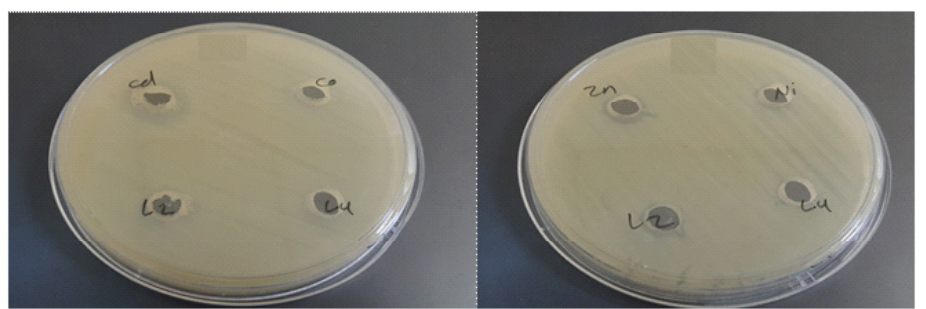

Fig. 14. The effect of $L^{1} L^{2}$ and its complexes on Staphylococcus aureus 


\section{CONCLUSION}

The preparation and characterisation of mixed ligands and their complexes are described. This was based on the preparation of two sorts of ligands; (i) the azo-linked Schiff-base ligand that obtained by reaction of the precursor with $\left(\mathrm{CH}_{3}\right)_{2} \mathrm{NC}_{6} \mathrm{H}_{4} \mathrm{CHO}$ and (ii) the DTCs ligand that fabricated by reaction of
$\left(\mathrm{C}_{6} \mathrm{H} 5\right)_{2} \mathrm{NH}$ with carbon disulphide. The mixed ligand complexes were achieved by adding the $\mathrm{HL}^{1}$ and $\mathrm{L}^{2}$ with the appropriate metal salt in a 1:1:1 mole ratio. Physico-chemical and spectroscopic methods were implemented to confirm mode of bonding and over all structure of the complexes. These results lead to the preparation of four and six coordinate complexes.

\section{REFERENCES}

1. Thoraya A., Farghaly A. Z., Arkivoc., 2008, 17, 295.

2. Chandravadivelu G., Senniappan P., Int.J. Pharm. Chem., 2011. 1(4), 1082-1086.

3. Hakimi M., Kukovec B., Minoura M., CrystallogrA., 2012, 2 (11), 475.

4. NabipourH., Ghammamy S., AshuriS., Aghbolaghc Z. S., Org. Chem. J., 2010, 2, 75-80.

5. Kanchi S., Singh P., Bisetty., 2014, 7, 11-25.

6. Singh S., Bhattacharya N., Subrato J., Organomet.Chem., 2012, 700, 69-77.

7. Normah A., Farahana N., Ester B, Asmah H., Rajab N., Halim A., Res. J. Chem. Environ., 2011, 15, 544-549.

8. Tlahuext H., Reyes-Martinez R., VargasPineda G., Lopez-Cardoso M., Hopfl H, J. Organomet.Chem., 2011, 6(96), 693-701.

9. Kocaokutgen H., Erdem E., Synth React Inorg Met-Org Chem., 2004, 34, 1843. doi:10.1081/ SIM-200030245.

10. Law K.Y., Tarnawskyj I.W., Lubberts P.T., Dyes Pigment., 1993, 23, 243. doi:10.1016/01437208(93)80039-4.

11. Fessenden R.J., Fessenden J.S., Organic chemistry, 4th edn, Cole Publishing Company, California,1990, 13, 610-615.

12. Uppadine L. H., Weeks J. M., Beer P. D., J. Chem. Soc. Dalton Trans., 2001, 22, 3367-3372.

13. Pratt M. D., Beer P. D., Tetrahedron., 2004. 60(49),11227-11238.

14. Cookson J., Evans E. A. L., Maher J. P., Serpell C., Paul R. P., Cowley A. R., Drew M., Beer P. D., Inorg. Chimica .Acta., 2010, 363(6), 1195-1203.

15. ParikhV.M., Absorption spectroscopy of Organic Molecules., Translated By Abdul HussainKhuthier, Jasim, M.A., Al-Rawi, and Mahammed A. Al-Iraqi., 1985.

16. SilverschtienR.M., Bassler and Morril, "Spectrophotometers Indentification of
Organic Compound", Translated by Ali Hussain and Suphi Al-Azawi., 1981.

17. Souza P., Jose. A., Vazguez G., Masaguer J. R., Trans. Met. Chem., 1985, 10, 410 .

18. NakamotoK., Infrared and Raman Spectra of Inorganic and Coordination Compounds., 1978. John Wiley. New York., 1978, 232.

19. Aime S., Bottaand M., Casellato U., Inorg. Chem.,1995, 34, 5825.

20. Socrates.G., Infrared Characteristic Group Frequencies., Wiley. New York., 1980.

21. Faraglia G., Sitran S., Montagner D., Pyrrolidinedithiocarbamates of $\mathrm{Pd}(\mathrm{II})$., Inorg. Chim. Acta., 2005, 358, 971-980.

22. Yin D., Zhai J., Sun Y-Y., Wang D-Q., Polyhedron., 2008, 27(2), 663-670.

23. N. Sarikavakli and G. Irez, Turk. J. Chem., 2005, 29, 107-115.

24. Canpolat E., Kaya M., J. Coord. Chem., 2005. 31(7), 511-515.

25. Geary W.J., Russian J. Coord. Chem. Rev., 1971, 7, 81-122.

26. Nejati K., RezvaniZ.,New J. Chem., 2003.27, 1665-1669.

27. Mikuraya M., SasakiT.,AnjikiA., Ikenoue S., Tokh T. Bull Chem. Soc., 1992, 65-334.

28. Lee M., YS. Yoo.Y.,Chol M., Macromolecules., 1999, 32, 2777.

29. Agrawal R. K., Prasad S., GahlotN., Twk. J. Chem., 2004, 28.

30. Al-JanabiA.E., M.Sc. Thesis., University of Baghdad. 2005.

31. AddisonA.W., T.N. RaoT.N., Sinn E., Inorg. Chem.,1984, 23, 1957-1967.

32. Preti C., Tosi G., Can J. Chem., 1977. 55, 1409.

33. Al-Jeboori M. J., Al-Jebouri F. A., Al-Azzawi M. A. R., Inorg. Chim. Acta., 2011, 379(1),163-170.

34. Erdem E., Sari E.Y., Kilinçarslan R., Kabay N., Trans. Met. Chem., 2009, 34, 167-174.

35. Kasawaki A. J., Chem. Soc. Perkins Trans ., 1990, 2, 223. 
36. Siddiqi K. S., Nami S. A. A., Lutfullaha, Chebudeb Y., J. Braz. Chem. Soc., 2006. 17(1), 107-112.

37. Al-Jeboori M.J., Al-Tawel H.H., Ahmad R.M., Inorg. Chim. Acta., 2010, 363(6), 1301-1305.

38. SIddappa K., Mallikarjun K., Reddy T., Mallikarjun M., reddy C.V., Tambe M., E-Journal of Chemistry., 2009. 6(3), 615-624.

39. Mamba S. M., Mishara A. K., Mamba B. B., Njobeh P. B., Dutton M. F., Fosso-Kankeu E., SpectrochimicaActa part A., 2010. 77(3), 579-587.

40. Bain G. A., Berry J. F., Diamagnetic corrections and Pascal's constants., J. Chemi. Educ., 2008, 85(4), 532.

41. Lever A.B.P., Inorganic Electronic Spectroscopy, second ed., Elsevier Publishing, New York.1984.

42. JinY., Yoon I., J. Seo J., LeeJ-E, MoonS-T., J.
Kim, SW. Han, K-M. Park, LF. Lindoy and SS. Lee, Dalton Trans., 2005, 4, 96-788.

43. Al-Jeboori M.J., Ahmed R. M., Hamdan T.A., Numan A.T., Potgieter .H., Complex Metals., 2014. 1(1), 38-45.

44. Himanshu A., Francesc L., Rabindranath M., Euro. J .Inorg. Chem., 2009, 22, 3317-3325.

45. Qing C., Ming-Hua Z., Lian-Qiang W., MohamedallyK., Chem. Mater., 2010, 22, 4328-4334.

46. Rahman A., Choudhary M., Thomsen W., Bioassay Techniques For Drug Development., Harwood Academic. Amsterdam. The Netherlands. 2001.

47. Singh R. V., Dwivedi R., Joshi S. C., Trans. Met .Chemi., 2004, 29(1), 70-74.

48. Tweedy B. G., "Plant extracts with metal ions as potential antimicrobial agents", Phytopathology.,1964. 55, 910-914. 